\title{
MANAJEMEN MUTU PELAYANAN KESEHATAN
}

\author{
Rizanda Machmud*
}

\section{Pendahuluan}

Saat ini mutu layanan kesehatan merupakan fokus utama bagi masyarakat. Kesadaran dan kepedulian terhadap mutu memang semakin meningkat. Hal-hal yang berkaitan dengan mutu saat ini antara lain : kepercayaan bahwa sesuatu yang bermutu pastilah merupakan hal yang bersifat luks, mewah, dan mahal. Mutu juga dianggap sesuatu hal yang bersifat abstrak sehingga tidak dapat diukur Upaya peningkatan mutu memerlukan biaya yang cukup mahal.

\section{Apa yang Disebut Mutu? \\ Definisi Mutu}

Menurut Ali Gufran, 2007; istilah mutu memiliki banyak penafsiran yang mungkin berbeda-beda, ketika ia digunakan untuk menggambarkan sebuah produk atau pelayanan tertentu. Bisa saja beberapa orang mengatakan bahwa sesuatu dikatakan bermutu tinggi ketika sesuatu tersebut dianggap lebih baik, lebih cepat, lebih cemerlang, lux, lebih wah dan biasanya lebih mahal dibandingkan produk atau layanan yang mutunya dianggap lebih rendah. Hal ini tentu tidak sepenuhnya benar. Beberapa orang mengartikan layanan kesehatan bermutu adalah layanan yang memuaskan pelanggan. Padahal layanan yang diberikan tidak memenuhi standar pelayanan medis profesional. Bahkan bisa terjadi di sebuah institusi layanan kesehatan seperti rumah sakit jika pasien datang di Unit Gawat Darurat langsung ditangani "diinfus". Pasien puas karena mereka merasa langsung "ditangani" padahal infus tidak selalu diperlukan. Bahkan jika tidak terkontrol dapat menimbulkan efek samping seperti oedem pulmo ${ }^{1,2}$.

Ada dilema dalam upaya untuk mewujudkan mutu dalam layanan kesehatan. Pada satu pihak mutu juga diartikan sejauh mana layanan kesehatan yang diberikan sesuai dengan standard operating procedure (SOP) atau prosedur tetap medis. Ketika SOP tersebut dilaksanakan seperti misalnya di beberapa rumah sakit pendidikan milik pemerintah, dianggap oleh pasien terlalu lama dan berbelitbelit. Dari pihak lainnya, menurut kacamata pasien, justru rumah sakit pendidikan milik pemerintah dianggap kurang bermutu dibanding rumah sakit swasta yang bisa lebih cepat karena prosedur yang diterapkan lebih fleksibel ${ }^{1,2}$.

Lebih lanjut dalam uraian Ali Gufran, 2007; layanan bermutu dalam pengertian yang luas diartikan sejauh mana realitas layanan kesehatan yang diberikan sesuai dengan kriteria dan standar profesional medis terkini dan baik yang sekaligus telah memenuhi atau bahkan melebihi kebutuhan dan keinginan pelanggan dengan tingkat efisiensi yang optimal. Abstrak mutu dapat dinilai dan diukur dengan berbagai pendekatan. Pendekatan maupun metode pengukuran yang digunakan dalam upaya meningkatkan mutu tersebut telah tersedia baik dari dimensi input, proses dan output. Mutu memiliki karakteristik melakukan pelayanan yang benar dengan cara yang benar, pertama benar dan selanjutnya diharapkan benar ${ }^{1,2}$.

\section{Perkembangan Upaya Perbaikan Mutu Pelayanan kesehatan di Indonesia}

Sejarah perkembangan tentang upaya perbaikan mutu yang dikutip dari Tjahyono Koentjoro, 2004 menerangkan bahwa upaya perbaikan mutu dan kinerja pelayanan kesehatan di Indonesia telah mulai di lakukan sejak tahun 1986 dengan diterapkannya gugus kendali mutu di rumah sakit dan di puskesmas serta pada pelayanan kesehatan yang lain. Perbaikan ini dilanjutkan dengan dikenalkannya total quality management pada tahun 1994 dan performance management pada tahun $1996^{3}$.

Untuk pelayanan kesehatan dasar di Puskesmas, diperkenalkan program jaminan mutu (quality assurance) pada tahun 1995 di Provinsi Jawa Barat, Jawa timur, Nusa Tenggara Barat, Kalimantan Barat, Kalimantan Tengah, dan Sumatera Barat melalui Proyek Kesehatan IV (Health Project IV). Di Jawa Tengah, pelayanan kesehatan tersebut diperkenalkan melalui Proyek Community Health and Nutrition III, sedangkan di Provinsi Daerah Istimewa Yogyakarta, pengenalan dilakukan melalui Provincial Health Project I dengan tiga tahapan, yakni analisis sistem, supervisi dan pembinaan, dan pendekatan tim. Empat standar pelayanan telah disusun melalui program jaminan mutu tersebut, yaitu standar penanganan diare, standar pelayanan imunisasi, standar penanganan infeksi saluran nafas atas, dan standar pelayanan antenatal, dalam bentuk lembar periksa yang harus diikuti oleh petugas pelayanan kesehatan di puskesmas ${ }^{3}$.

\section{Apa Saja Prinsip Penting dalam Perbaikan Mutu?}

Dua hal yang perlu dipantau dalam upaya perbaikan mutu adalah Kepuasan Pelanggan dan Standar Pelayanan Kesehatan. Kedua aspek ini haruslah seimbang.

\section{Kesetiaan dan Kepuasan Pelanggan}

Dari berbagai sumber disebutkan bahwa. Prinsip

\footnotetext{
* Staf Pengajar PSIKM FK Unand
} 
utama perbaikan mutu dan kinerja pelayanan kesehatan adalah kepedulian terhadap pelanggan. Pasien sebagai pelanggan eksternal tidak hanya menginginkan kesembuhan dari sakit yang diderita yang merupakan luaran (outcome) pelayan, tetapi juga merasakan dan menilai bagaimana ia diperlakukan dalam proses pelayanan ${ }^{3,4}$.

Berangkat dari pelayanan yang peduli pada pelanggan, yakni pelayanan yang memerhatikan kebutuhan (needs), harapan (expectation) pelanggan, dan penilaian manfaat (value) oleh pelanggan sebagai persyaratan yang diajukan oleh pelanggan, upaya untuk memperbaiki mutu dan kinerja perlu merujuk pada trilogi persyaratan pelanggan tersebut. Harapan (expectation) dari pelanggan tidak hanya diartikan seperti apa yang diinginkan atau diharapkan akan didapatkan oleh pelanggan, tetapi juga apa yang diharapkan terjadi selama menjalani proses pelayanan dan menikmati produk yang dibeli, yang antara lain tidak akan mengalami kesalahan tindakan medis ataupun kejadiankejadian yang tidak diinginkan ${ }^{3}$.

Hasil pelayanan kesehatan adalah luaran klinis, manfaat yang diperoleh pelanggan, dan pengalaman pelanggan yang berupa kepuasan atau kekecewaan. Pengalaman pelanggan tersebut sangat tergantung pada proses pelayanan pada lini depan atau sistem mikro pelayanan, suatu sistem pelayanan yang bersentuhan langsung dengan pelanggan ${ }^{3}$.

\section{Standar Pelayanan Kesehatan}

Dalam proses pelayanan kesehatan akan terjadi variasi pelaksanaan kegiatan dari waktu ke waktu yang akan menghasilkan luaran yang bervariasi juga. Salah satu upaya untuk mengurangi variasi proses adalah dengan melakukan standardisasi. Proses standardisasi meliputi penyusunan, penerapan, monitoring, pengendalian, serta evaluasi dan revisi standar (PP 102/2000) $)^{3-6}$.

Keberadaan standar dalam pelayanan kesehatan akan memberikan manfaat, antara lain mengurangi variasi proses, merupakan persyaratan profesi, dan dasar untuk mengukur mutu. Ditetapkannya standar juga akan menjamin keselamatan pasien dan petugas penyedia pelayanan kesehatan. Dikuranginya variasi dalam pelayanan akan meningkatkan konsistensi pelayanan kesehatan, mengurangi morbiditas dan mortalitas pasien, meningkatkan efisiensi dalam pelayanan, dan memudahkan petugas dalam pelayanan ${ }^{2,3}$.

\section{Bagaimana Melakukan Perbaikan Mutu?}

Pada pembahasan ini akan diutarakan lebih lanjut bagaimana upaya yang dilakukan dalam perbaikan mutu, fokus apa yang perlu diperhatikan. Fokus tersebut yang harus diperhatikan dalam Rantai Efek Perbaikan Mutu Pelayanan Kesehatan

Menurut Tjahyono Koentjoro 2004, Untuk melakukan perbaikan mutu pelayanan kesehatan, perlu diperhatikan empat tingkat perubahan, yaitu :

1. Pengalaman pasien dan masyarakat

2. Sistem mikro pelayanan

3. Sistem organisasi pelayanan kesehatan

4. Lingkungan pelayan kesehatan

Di samping harus memiliki tujuan yang jelas dan komprehensif, pelayanan kesehatan yang harus berfokus pada pelanggan. Pengalaman pasien dan masyarakat yang menjadi pelanggan pelayanan kesehatan harus mendapat perhatian utama sehingga kebutuhan, harapan, dan nilai pelanggan dapat dipenuhi oleh organisasi pelayanan kesehatan. Mekanisme untuk mengenal adanya perubahan kebutuhan, harapan, dan nilai pelanggan perlu ada dalam pengelolaan organisasi pelayanan kesehatan, demikian juga mekanisme untuk mengelola pengalaman pelanggan. Dengan demikian, organisasi pelayanan kesehatan akan mampu memberikan yang terbaik kepada pasien dan masyarakat ${ }^{3}$.

Berikut pendekatan-pendekatan yang dilakukan dalam upaya mewujudkan pelayanan kesehatan yang harus berfokus pada pelanggan seperti Total Quality Management (TQM), Layanan Prima.

\section{Total Quality Management (TQM)}

Sejak empat dekade yang lalu, Joseph Juran (1974) telah menggambarkan komponen-komponen dasar pendekatan manajemen kualitas secara komprehensif. Juran telah mengidentifikasikan elemen-elemen yang diperlukan dalam sebuah sistem untuk mengukur, meningkatkan, dan merancang proses yang secara konsisten dapat memberikan hasil yang optimal. Dia menamakan sistem tersebut sebagai manajemen kualitas secara menyeluruh atau Total Quality management $t^{1,3,4}$.

Menurut Ali Gufran, 2007, Dalam Total Quality management, seluruh aspek dalam organisasi memerlukan perubahan secara luas dan mendasar pada budaya organisasi dan sifat dan kharakter manajemen. Kegiatankegiatan peningkatan kualitas ini merupakan bagian dari rencana bisnis organisasi. Seluruh tingkat manajemen mulai dari top manajemen sampai front-liner mereka yang paling terdepan dalam memberikan layanan pada pasien menghargai pentingnya mutu dan data statistik. Selain itu, Total Quality management juga dimaknai sebagai proses memobilisasi sumber daya manusia untuk meraih tujuan mutu. Secara internal, proses tersebut termotivasi oleh perhatian yang besar terhadap praktik-praktik pencegahan timbulnya masalah mutu layanan ${ }^{1-5}$.

Merujuk kepada arti kata dari Total Quality management itu, total berarti bahwa kegiatan tersebut dilaksanakan di seluruh tingkatan dan seluruh bagian atau departemen dalam organisasi serta pada seluruh waktu (setiap hari). Sementara itu, istilah quality menggambarkan peningkatan yang berkelanjutan untuk memenuhi kebutuhan pelanggan. Di satu sisi, management merupakan keseluruhan sistem dan lingkungan yang mendukung budaya peningkatan mutu secara berkelanjutan tersebut ${ }^{2,4}$. 
Tabel 1.

Perbandingan pemikiran tradisional dan Total Quality Management

\begin{tabular}{|c|c|}
\hline Tradisional & $T Q M$ \\
\hline $\begin{array}{l}\text { - Peningkatan mutu merupakan tanggung } \\
\text { jawab pihak manajemen } \\
\text { - Pelanggan merupakan pihak luar dan kita } \\
\text { menjual kepada mereka } \\
\text { - Cukup baik adalah cukup baik } \\
\text { - Kita membutuhkan orang-orang yang lebih } \\
\text { baik untuk meningkatkan mutu } \\
\text { - Vendor dan pemasok adalah bukan bagian } \\
\text { dari kita, melainkan relasi } \\
\text { - Mutu diperoleh dari inspeksi, rejeksi, dan } \\
\text { kerja ulang } \\
\text { - Jika tidak ada yang rusak, tidak perlu } \\
\text { diperbaiki }\end{array}$ & $\begin{array}{l}\text { - Peningkatan mutu merupakan tanggung } \\
\text { jawab setiap anggota dalam organisasi } \\
\text { - Pelanggan (internal dan eksternal) } \\
\text { merupakan bagian vital organisasi } \\
\text { - Tidak ada yang kurang dari } 100 \% \text { usaha } \\
\text { yang dilakukan } \\
\text { - Kita telah memiliki orang-orang terbaik } \\
\text { untuk yang mereka kerjakan } \\
\text { - Vendor dan pemasok adalah anggota } \\
\text { penting dari tim kita } \\
\text { - Mutu dibangun dalam pelayanan dan } \\
\text { produk mulai dari awal input dan proses } \\
\text { - "Jika tidak rusak, tingkatkankah" } \\
\text { Peningkatan yang terus-menerus } \\
\text { merupakan satu-satunya jalan } \\
\text { - Peningkatan kualitas akan menurunkan }\end{array}$ \\
\hline & \\
\hline
\end{tabular}

Sumber : Ali Ghufron Mukti, Strategi Terkini Peningkatan Mutu Pelayanan Kesehatan: Konsep dan Implementasi, Pusat Pengembangan Sistem Pembiayaan dan Manajemen Asuransi/ Jaminan Kesehatan Fakultas Kedokteran Universitas Gajah Mada, 2007.

Lebih lanjut Ali Gufran, 2007 mengulas, mengapa kita menggunakan Total Quality management? Hal ini disebabkan karena keempat prinsip yang dimiliki oleh $T Q M$ akan sangat membantu dalam upaya peningkatan mutu layanan kesehatan. Keempat prinsip itu adalah ${ }^{2,4}$ :

1) Mengukur mutu sehingga dapat mengelolanya;

2) Melakukan perncanaan secara strategis sehingga dapat berpikir jangka panjang, tetapi tetap melakukan aksi-aksi jangka pendek;

3) Menghimpun kekuatan otak dan gagasan dari setiap orang di organisasi sehingga diperoleh manfaat dari sinergi yang sedang dan telah dibangun, serta

4) Berfokus kepada pasien (customer focused) sehingga dapat memberi mereka kepuasan

Dengan demikian, terdapat beberapa asumsi mengenai pelaksanaan TQM, yaitu fokus kepada konsumen, penglibatan secara total seluruh komponen dalam organisasi layanan kesehatan termasuk dokter, karyawan dan seluruh orang yang ada dalam strukturstruktur yang terdapat di dalamnya, serta pengukuran, dukungan sistematis, dan peningkatan mutu layanan yang berkelanjutan ${ }^{2,4}$.

Program TQM tersebut dikatakan berhasil apabila telah terjadi serangkaian perubahan-perubahan mendasar tentang banyak hal termasuk paradigma berpikir dan cara pandang. Misalnya, bagaimana anda melihat pelanggan, melihat komunitas yang dihadapi, melihat karyawan, melihat hubungan yang terjalin, dan juga perubahan dalam budaya organisasi atau perusahaan dan perubahan dalam mindset atau cara berpikir ${ }^{2,4}$.
Oleh karena itu, untuk menjamin agar program peningkatan mutu ini dapat berhasil dan berjalan sukses, perlu keyakinan mengenai kesiapan dan iklim budaya organisasi, komunikasi, dan komitmen berbagai pihak, serta perhatian terhadap pendidikan dan perwujudan dari rencana strategis yang telah disusun bersama.

\section{Pelayanan prima}

Dari kutipan yang diambil dari buku Strategi Terkini Peningkatan Mutu Pelayanan Kesehatan: Konsep dan Implementasi; Pelayanan prima dimaknai sebagai pelayanan terbaik dan telah memenuhi standar pelayanan dipandang dari perspektif pengguna atau donor, perspektif proses pelayanan dan perspektif keuangan yang dapat dicapai jika kualitas sumber daya manusianya cukup profesional. Sementara itu, LAN RI mengartikan pelayanan prima sebagai pelayanan yang terbaik dan melebihi, melampaui, serta mengungguli pelayanan yang diberikan pihak lain atau pelayanan sebelumnya ${ }^{2}$.

Istilah pelayanan prima sendiri merupakan terjemahan dari excellent service, yang secara harfiah berarti pelayanan yang sangat baik atau pelayanan yang terbaik. Yang menjadi permasalahan adalah bagaimana maksud pelayanan yang sangat baik atau yang terbaik dalam konteks pelayanan kesehatan atau rumah sakit. Departemen kesehatan telah memberikan pengertian pelayanan prima. Pelayanan prima adalah pelayanan kepada pasien berdasarkan standar mutu untuk memenuhi kebutuhan dan keinginan pasien sehingga pasien dapat memperoleh kepuasan yang akhirnya dapat meningkatkan kepercayaannya kepada rumah sakit ${ }^{2}$. 
Dalam usaha untuk mencapai usaha Indonesia sehat 2010, Departemen Kesehatan menjelaskan bahwa pelayanan prima seharusnya meliputi aspek-aspek berikut:

- Kemudahan akses informasi (aspek kepuasan pengguna)

- Pelaksanaan peraturan secara tepat, konsisten, dan konsekuen (aspek proses pelayanan)

- Pelaksanaan hak dan kewajiban pemberi dan penerima pelayanan (aspek SDM dan kepuasan pelanggan)

- Penanganan dan pendokumentasian kegiatan pelayanan dilakukan oleh tenaga yang berwenang/ kompeten (aspek proses dan SDM)

- Penciptaan pola pelayanan yang sesuai dengan sifat dan jenisnya sebagai efisiensi dan efektivitas (aspek SDM, dan proses pelayanan)

- Penetapan tarif sesuai dengan kemampuan masyarakat dengan mekanisme pungutan yang transparan serta adanya pengendalian dan pengawasan yang cermat (aspek finansial dan kepuasan pelanggan)

- Tidak ada pembedaan dalam memberikan pelayanan serta pemerataan distribusi cakupan (aspek kepuasan pelanggan)

- Kebersihan fasilitas pelayanan dan lingkungan (aspek proses pelayanan)

- Sikap ramah dan sopan petugas serta meningkatkan kinerja secara kualitatif dan kuantitatif dengan kapasitas optimal (aspek kepuasan pelanggan dan aspek SDM)

\section{BAGAIMANAAGAR MUTUTETAPTERUS TERJAGA?}

Dalam upaya menjaga mutu layananan kesehatan agar terus bekesinambungan maka diperlukan suatu proses perbaikan mutu yang bekesinambungan.

\section{Perbaikan Proses Berkesinambungan (Continuous Process Improvement)}

Upaya perbaikan proses yang berkesinambungan pada sistem mikro pada dasarnya mengikuti siklus Deming: Perencanaan (Plan), Dikerjakan (Do), Cermati hasilnya (Check), dan Amalkan untuk seterusnya (Action), yang dikenal dengan siklus PDCA.

Salah satu model perbaikan pada sistem mikro adalah model Nolan (Langley dkk, 1996). Nolan memperkenalkan suatu model perbaikan sistem mikro pelayanan yang pada prinsipnya tidak terlepas dari langkah-langkah proses perbaikan yang meliputi: Perencanaan (Plan), Dikerjakan (Do), Cermati hasilnya (Check), dan Amalkan untuk seterusnya (Action). Akan tetapi, harus ada kejelasan terlebih dahulu mengenai apa yang menjadi sasaran perbaikan sebelum dilakukan perubahan (setting aims), dilanjutkan dengan cara untuk mengetahui bahwa perubahan yang dilakukan akan menghasilkan perbaikan (measurement). Setelah menetapkan sasaran perbaikan dan menetapkan pengukuran atas perubahan, barulah ditetapkan dan direncanakan kegiatan-kegiatan perbaikan pada apa saja yang perlu dilakukan dalam bentuk siklus PDCA yang multipel.

Pada dasarnya, langkah perbaikan sistem mikro pelayanan model Nolan terdiri dari tujuh langkah, yaitu:

1. Bentuk tim

2. Tetapkan sasaran perbaikan

3. Tentukan pengukuran

4. Pilih perubahan yang perlu dilakukan

5. Uji coba beberapa perubahan dalam skala kecil

6. Implementasikan perubahan

7. Sebarkan ke unit yang lebih luas

\section{Apa yang ingin kita capai? \\ Bagaimana kita tahu bahwa perubahan yang dilakukan adalah perbaikan? \\ Perubahan apa yang dapat kita lakukan yang hasilnya adalah perbaikan?}

Amalkan untuk seterusnya

Cermati Hasilnya

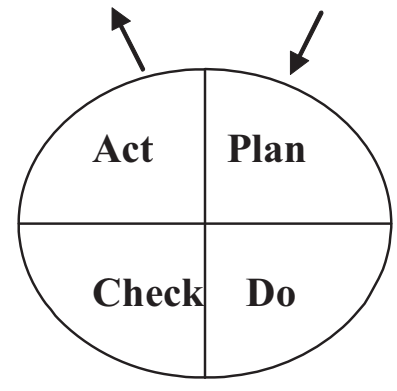

Perencanaan

Diujicoba dilaksanakan

Gambar 1. Model Perbaikan Sistem Mikro (Nolan)

Sumber: Tjahyono Koentjoro, Regulasi Kesehatan di Indonesia, Andi Yogyakarta, 2007 


\section{Apa Saja Alat-alat Peningkatan Mutu (Quality Tools)?}

Berdasarkan berbagai asupan, antara lain keluhan pelanggan, hasil audit internal, hasil surveilan kepuasan pelanggan, hasil tinjauan manajemen, serta hasil studi kasus, dapat disimpulkan adanya berbagai masalah atau adanya potensi terjadinya masalah yang harus dikoreksi atau dicegah kemunculannya di kemudian hari. Sasaran mutu disusun berdasarkan adanya hasil identifikasi masalah, baik yang telah terjadi maupun yang potensial yang akan terjadi, dan peluang-peluang untuk perbaikan yang diharapkan akan lebih memuaskan pelanggan ${ }^{2,3}$.

Untuk menganalisis masalah, menetapkan sasaran mutu, menganalisis masalah, dan menyusun rencana perbaikan digunakan berbagai alat perbaikan mutu, baik menggunakan maupun tidak menggunakan metode statistik. Alat-alat tersebut adalah:

a. Alat-alat mutu bukan statistik (Non-statistical tools) merupakan alat untuk mengembangkan ide,

\section{DAFTAR PUSTAKA}

1. Djoko Wiyono, Manajemen Mutu Pelayanan Kesehatan, Airlangga University Press, 2000.

2. Ali Ghufron Mukti, Strategi Terkini Peningkatan Mutu Pelayanan Kesehatan: Konsep dan Implementasi, Pusat Pengembangan Sistem Pembiayaan dan Manajemen Asuransi/ Jaminan Kesehatan Fakultas Kedkteran Universitas Gajah Mada, 2007.

3. Tjahyono Koentjoro, Regulasi Kesehatan di Indonesia, Andi Yogyakarta, 2007 mengelompokkan, memprioritaskan, dan memberikan arah dalam pengambilan keputusan. Alat-alat tersebut meliputi:

- curah pendapat

- multivoting

- matriks prioritas masalah

- fishbone

- bagan alir

- failure mode and effect analysis

- bagan gantt

b. Alat-alat mutu statistik (Statistical tools), yang meliputi:

- lembar periksa (check sheet)

- diagram kecendrungan (run chart)

- diagram pencar

- histogram

- diagram Pareto

- diagram kendali
4. AA Gde Muninjaya, Manajemen Kesehatan, Edisi 2, Penerbit Buku Kedokteran EGC, 2004

5. Fandy Tjiptono \& Anastasia Diana, Total Quality Management (TQM), edisi Revisi, Andi Yogyakarta, 2003

6. HAS Moenir, Manajemen Pelayanan Umum di Indonesia, Bumi Aksara, 2006 